УДК 336

DOI: https://doi.org/10.26642/jen-2021-1(95)-76-86

\author{
В.А. Топило, аспірант \\ Державний університет «Житомирська політехніка»
}

В.К. Данилко, д.е.н., проф.

\title{
Концептуальні засади становлення та функціонування вертикально інтегрованих структур
}

\begin{abstract}
Стаття присвячена дослідженню концептуальних засад створення та функиіонування вертикально інтегрованих структур у вітчизняній економіці. Незважаючи на значний науковий внесок авторів у дослідження иієї тематики, існує низка невирішених питань щзодо виокремлення напрямів, форм, видів вертикальної інтеграчії, які потребують додаткового вивчення та уточнення. Метою написання статті є дослідження концептуальних засад створення та функціонування вертикально інтегрованих структур, уточнення економічного змісту вертикальної інтеграції та розробка ії класифікаційної моделі. На підставі проведення декомпозиційного аналізу уточнено поняття «вертикально інтегрована структура», під якою слід розуміти форму функціонування підприємницької структури, яка виникла шляхом об'єднання фінансових, виробничих, трудових ресурсів суб'єктів різноманітних організаційно-правових форм, щчо пов'язані технологічним ииклом (процесом постачання, виробництва та реалізацї продукиії), з метою одержання максимального синергетичного ефекту та стратегічних конкурентних переваг. Розроблено класифікаційну модель вертикально інтегрованих структур, в межах якої виокремлено такі ознаки класифікаиії та групи вертикально інтегрованих структур: 1) за походженням капіталу (начіональні, іноземні, змішані); 2) за видами (картель, холдинг, трест; асоиіація; синдикат; конгломерат); 3) за ступенем інтеграції (повна інтеграція 3 поділом на природну та інтеграцію шляхом злиття; квазіінтеграція з поділом на стратегічні союзи (альянси), спільні підприсмства, володіння активами, перехресне володіння акціями; франчайзинг; довгострокові контракти); 4) за напрямами інтеграчії (розвиток виробничих зв'язків; акумуляція фінансових ресурсів; реалізація інноваційно-інвестиційних проєктів; розвиток торговельного співробітництва). Навідміну від існуючих класифікацій запропоновано нову ознаку: за рівнем контролю та підпорядкування - дозволяє виокремити вертикально інтегровані структури з надмірним контролем і структури зі слабким контролем, щуо відображає ступінь залежності підпорядкованих суб'єктів від управлінських рішень головної (материнської) компанії. Запропонована класифікація сприятиме уточненню теоретичних основ, покладених в основу дослідження вертикально інтегрованих структур, та є базою для вивчення їх особливостей залежно від вирізнених ознак.
\end{abstract}

Ключові слова: вертикально інтегровані структури; класифікаційна модель; квазіінтеграція; ступінь інтеграції; форма інтеграції; напрям інтеграції.

Постановка проблеми у загальному вигляді та ї̈ зв'язок 3 важливими практичними завданнями. Становлення та активне функціонування вертикально інтегрованих підприємницьких структур є однією 3 ознак сучасної світової економіки, що обумовлено необхідністю концентрації фінансових ресурсів, прагненням підвищити конкурентоспроможність та вийти на світові ринки збуту продукції (товарів). Ефективна діяльність таких підприємств впливає не лише на мікроекономічному, а й на макроекономічному рівнях. Це виражається у заповненні «провалів ринку» шляхом формування внутрішнього ринку капіталу, стимулювання інноваційних процесів в економіці, усунення низки структурних проблем. Водночас великі бізнес-структури, сформовані шляхом вертикальної інтеграції, можуть створювати дисбаланси під час концентрації капіталу, ускладнювати вхід менш конкурентоспроможних суб'єктів господарювання на ринок, сприяти його монополізації. Це вимагає вивчення концептуальних засад становлення та функціонування вертикально інтегрованих структур 3 позиції підвищення їх конкурентних переваг та паритетності інтересів держави.

Аналіз останніх досліджень та публікацій. Становлення вертикально інтегрованих структур, їх види, умови та принципи формування достатньо широко досліджувалися у працях вітчизняних вчених: О.Коваленка, О.Станіславика [7] - щодо особливостей становлення вертикальних структур у харчовій промисловості; В.С. Ніценко [11] - щодо класифікації таких структур за різними ознаками в аграрному секторі; Ю.Соловей [14] - щодо особливостей поширення інтегрованих структур в АПК. Незважаючи на значний науковий внесок авторів у дослідження тематики створення інтегрованих структур, існує низка невирішених питань щодо виокремлення напрямів, форм, видів вертикальної інтеграції, які потребують додаткового вивчення та уточнення.

(C) В.А. Топило, В.К. Данилко, 2021 
Метою статті $є$ дослідження концептуальних засад створення та функціонування вертикально інтегрованих структур, уточнення економічного змісту вертикальної інтеграції та розробка іiі класифікаційної моделі.

Викладення основного матеріалу. Створення вертикально інтегрованих структур, які передбачають акумуляцію фінансових ресурсів, тісну взаємодію їх учасників, розвиток організаційної структури, $\epsilon$ важливим елементом інституційного середовища в умовах глобалізації. Основні історичні етапи становлення таких структур в Україні представлено в таблиці 1.

Таблиия 1

Еволючія становлення вертикально інтегрованих структур в Україні (складено за [10, 15])

\begin{tabular}{|c|c|c|}
\hline $\begin{array}{l}\text { № } \\
\text { 3/n }\end{array}$ & $\begin{array}{l}\text { Часові межі } \\
\text { етапу }\end{array}$ & Характеристика виокремленого етапу \\
\hline 1 & $1930-1940 \mathrm{pp}$. & Розвиток різноманітних форм кооперації з державною підтримкою \\
\hline 2 & $1960-1980 \mathrm{pp}$. & $\begin{array}{l}\text { Виникнення таких форм інтеграції, як спеціалізовані трести, індустріальні } \\
\text { комбінати, територіально-галузеві комплекси, одним } 3 \text { джерел фінансування } \\
\text { яких є асигнування з бюджету. Значне поширення ці форми інтеграції отримали } \\
\text { у сільському господарстві }\end{array}$ \\
\hline 3 & 1980-1990 pp. & $\begin{array}{l}\text { Перехід до ринкових відносин сприяв становленню аграрно-промислових } \\
\text { інтегрованих структур, формуванню галузевих консорціумів та інших видів } \\
\text { інтегрованих об'єднань }\end{array}$ \\
\hline 4 & 1991-1997 pp. & $\begin{array}{l}\text { Розрив ділових зв’язків, спричинений розпадом СРСР, обумовив пошук нових } \\
\text { форм вертикальної інтеграції, що призвело до розвитку торговельно-збутових } \\
\text { мереж }\end{array}$ \\
\hline 5 & 1997-2004 pp. & $\begin{array}{l}\text { Постприватизаційний розподіл власності, що призвів до перерозподілу капіталу } \\
\text { колишніх державних підприємств та створенню ринкових форм об’єднань }\end{array}$ \\
\hline 6 & $\begin{array}{c}2004 \text { p. }- \\
\text { до сьогодні }\end{array}$ & $\begin{array}{l}\text { Подальший розвиток інтеграційних формувань, зокрема, формування асоціацій, } \\
\text { концернів, трестів, фінансово-промислових груп, корпорацій тощо }\end{array}$ \\
\hline
\end{tabular}

Можна вирізнити такі основні передумови формування вертикально інтегрованих структур на сучасному етапі розвитку економіки: 1) глобалізація та зміцнення світогосподарських зв'язків між країнами; 2) спільне ведення господарської діяльності на основі більш ефективного використання фінансових, кадрових, виробничих ресурсів. Пояснення причин існування вертикально інтегрованих структур в економічній теорії наведено в таблиці 2.

Таблиия 2

Пояснення причин існування вертикально інтегрованих структур в економічній теорії (складено за [6, 9])

\begin{tabular}{|c|c|c|}
\hline $\begin{array}{l}\text { № } \\
3 / n \\
\end{array}$ & $\begin{array}{c}\text { Назва економічної } \\
\text { теорії }\end{array}$ & Пояснення вертикальної інтеграції в межах теорії \\
\hline 1 & $\begin{array}{c}\text { Неокласична теорія } \\
\text { фірми }\end{array}$ & $\begin{array}{l}\text { Наявність вертикальної інтеграції обумовлює виникнення ефекту від } \\
\text { масштабу, що визначає можливість вузької спеціалізації, диверсифікації } \\
\text { ризику, використання більш кваліфікованих працівників }\end{array}$ \\
\hline 2 & Інституц & $\begin{array}{l}\text { Вертикальну інтеграцію можна пояснити через трансакційні витрати, } \\
\text { права власності, агентські відносини. Розмір фірми залежить від } \\
\text { величини трансакційних витрат. Вертикальна інтеграція є формою } \\
\text { захисту від опортуністичної поведінки суб’єктів фінансових відносин }\end{array}$ \\
\hline 3 & $\begin{array}{c}\text { Динамічна теорія } \\
\text { трансакційних витрат }\end{array}$ & $\begin{array}{l}\text { Збільшення масштабу підприємства та зростання його влади на ринку } \\
\text { сприятиме впровадженню інноваційних проєктів }\end{array}$ \\
\hline
\end{tabular}

Концептуальні засади становлення та функціонування вертикально інтегрованих структур представлено на рисунку 1. Під час дослідження поняття «вертикально інтегровані структури» доцільно обгрунтувати поняття «інтеграції» та розкрити сутність їх форм і видів. Це є особливо важливим в умовах відсутності нормативного закріплення поняття «вертикальна інтеграція». Зокрема, А.Серобян визначає інтеграцію «... як об’єднання економічних суб’єктів, що супроводжується поглибленням їх взаємовпливу з постійним розвитком зв'язків і призводить до встановлення таких взаємовідносин, які здатні забезпечити довгостроковий позитивний ефект у вигляді гармонізації генеральної місії інтегруючого підприємства та цілей інтегрованих підприємств» [13, с. 36]. Аналізуючи це визначення зауважимо, що головною метою об’єднання (інтеграціі) є одержання позитивного економічного ефекту у довгостроковій перспективі, який досягається шляхом взаємодії певних суб'єктів. 


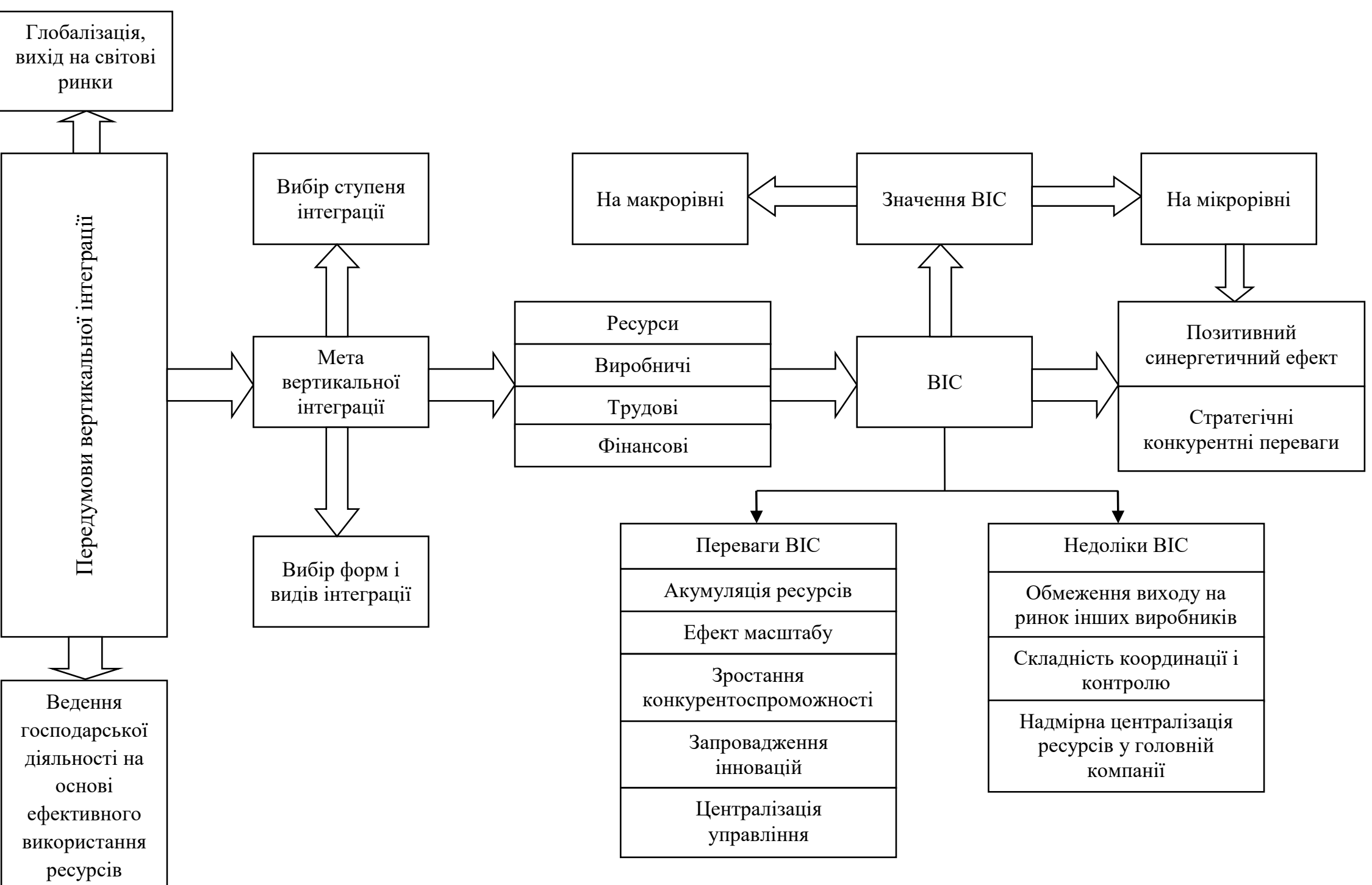

Рис. 1. Концептуальні засади дослідження вертикально інтегрованих структур (складено авторами) 
Безумовними перевагами функціонування інтегрованих структур є: 1) акумуляція ресурсів (матеріальних, трудових, фінансових, інформаційних), що дає можливість забезпечити отримання позитивного синергетичного ефекту; 2) перетворення конкурентних відносин між суб'єктами на відносини партнерства та співробітництва. Зокрема «рух валового продукту здійснюється в структурі інтеграційних, а не ринкових зв'язків», що перетворює ринковий механізм на «внутрішній або внутрішньовиробничий»; а щодо суб'єктів інтеграції, то всі стадії відтворення здійснюються в межах новоствореної ієрархічної системи; 3) підвищення конкурентоспроможності вертикально інтегрованих структур; 4) економія на витратах (ефект масштабу), у тому числі скорочення податкових, трансакційних, маркетингових, збутових витрат. Зокрема А.Ігнатюк пише, що «зниження на трансакційних витратах відбувається також при використанні фірмою високоспеціалізованих ресурсів, оскільки ринок цих активів фактично монополізований» [6, с. 21]; 5) потенційна можливість запровадження інноваційних проєктів, що обумовлена більшим обсягом наявних фінансових ресурсів. Такі структури сприятимуть пришвидшенню темпів технічного переоснащення й запровадження інновацій та інноваційних фондів; 6) можливість оптимізації розподілу прибутку в інтегрованій структурі; 7) централізація функцій управління та контролю, що передбачає єдиний підхід до формування фінансової політики вертикальної структури.

До зазначених вище переваг О.Криворучко додає ефективне впровадження інформатизації та уніфікацію технологічних процесів, наслідком чого $є$ підвищення ефективності виробництва й реалізації виготовленої продукції (шляхом застосування нових передових технологій, модернізації внутрішньовиробничого контролю, дотримання світових стандартів якості) [8]. Ігнатюк А., вивчаючи питання переваг інтегрованих структур у межах «теорії фірми», стверджує, що вертикальна інтеграція дозволяє використовувати більш кваліфіковані (вузькоспеціалізовані кадри); концентрувати засоби, диверсифікувати фінансовий ризик шляхом розподілу на більший обсяг діяльності підприємства, отримувати більший економічний ефект від витрат на просування та маркетинг продукції підприємства. Як приклад успішного функціонування вертикально інтегрованих структур автор наводить експортні та імпортозамінні галузі економіки, результатом діяльності яких $є$ покращення структури експорту; зростання конкурентних переваг; покращення показників господарської діяльності [6]. Соломчук Л.М., досліджуючи питання створення інтегрованих структур в агропромисловому секторі, зважаючи на його специфіку, зауважує «зацікавленість всіх учасників агропромислової інтеграції у розширенні виробництва, забезпечення пропорційного розвитку сільського господарства та переробних галузей, підвищення ефективності діяльності» [15, с. 103].

Стоянова-Коваль С. [16] до цього переліку переваг додає захист вітчизняних виробників від проникнення демпінгової продукції. $Є$ низка переваг існування вертикально інтегрованих структур, обумовлених належністю таких підприємств до конкретної галузі, наприклад, вертикальна інтеграція у харчовій промисловості та аграрному секторі сприятиме забезпеченню безперервності постачання сировини, раціональному використанню відходів виробництва, вирішенню екологічних проблем тощо.

У межах дослідження необхідно значення вертикально інтегрованих структур вивчати не лише на мікроекономічному, але й на макроекономічному рівнях. Це виражається у: вирішенні структурних проблем економіки; формуванні внутрішнього ринку капіталу; підвищенні рівня ефективності реального сектору економіки; зростанні конкурентоспроможності вертикальних структур на зовнішньому ринку; сприянні науково-технічному прогресу через впровадження інноваційних проєктів тощо. В цілому вертикально інтегровані структури сприяють концентрації інвестиційно-інноваційного потенціалу, $€$ ланкою, що пов'язує макроекономічний та мікроекономічний рівні [9]. Тому логічно досліджувати значення таких структур на мікро- та макрорівнях.

Водночас вертикально інтегровані структури містять низку недоліків, зокрема: 1) монопольне становище компаній, що обмежує вхід на ринок іншим виробникам; 2) значні витрати на управління підприємством, включаючи складність координації та контролю; 3) можливість дублювання функцій різними структурними підрозділами; 4) низький рівень спеціалізації виробництва; 5) надмірна централізація фінансових ресурсів у керуючій (головній) компанії; 6) можливість корпоративних конфліктів між керівним центром вертикально інтегрованої структури та окремими його учасниками.

Вертикальна інтеграція, згідно з визначенням А.Серобонян [13], - це організаційне поєднання форм суміжних технологічних операцій, що дозволяє об'єднати суб'єкти різних галузей, які пов'язані технологічним циклом (процесом постачання, виробництва та реалізації продукції). Водночас автор визначає лише технологічну мету об'єднання, не розглядаючи можливість концентрації фінансових, трудових та інших ресурсів, що потребує доповнення.

Деякі автори вертикальну інтеграцію (як результат інтеграційних процесів) ототожнюють зі злиттям підприємств різних стадій єдиної технологічної ланки (як процесом) [1, с. 9], що вважаємо неточним. Також на думку авторів статті, не зовсім коректним $є$ ототожнення вертикальної інтеграції 3 іiі наслідками - розширенням меж підприємств [10, с. 18]. У більшості опрацьованих джерел вертикальну інтеграцію досліджують 3 позиції отримання синергетичного організаційного ефекту [17]: 
це організаційне об’єднання підприємств суміжних технологічних операцій в межах спільної власності; однак водночас не приділяють увагу фінансовому ефекту в межах синергетичного.

Аналогічно О.Коваленко та О.Станіславик, досліджуючи інтеграційні утворення в агросекторі, визначають вертикально інтегровані структури як підприємницькі структури різних організаційноправових форм, що об'єдналися з метою оптимізації процесів виробництва, забезпечення єдності та безперервності відтворювального процесу та більш ефективного використання виробничої інфраструктури [7, с. 234]. Автори розширили розгляд можливого виробничого (технологічного) ефекту від створення інтегрованої структури до дослідження організаційного ефекту.

Найширше до трактування таких структур підходить С.Стоянова-Коваль, яка визначає вертикально інтегровану структуру як ефективну форму міжгосподарського співробітництва, що забезпечує іiі учасникам фінансово-економічну стабільність, виробничо-технічну й організаційно-управлінську єдність, високу конкурентоспроможність [16]. Науковець передбачає можливість інтеграції не лише виробничо-технологічних ресурсів та процесів, але й фінансових, організаційних і трудових. Визначаючи особливості вертикальної інтеграції у сільському господарстві, автор пише, що вона містить сукупність аграрних підприємств та підприємств переробної промисловості, а також підприємств зі зберігання й продажу кінцевої продукції, що дозволяє досліджувати три взаємопов'язані між собою ланки: виробництво - переробка - збут. Вивчаючи питання особливостей інтеграції підприємств в АПК, Ю.Соловей під вертикальною інтеграцією розуміє «... поглиблення зв'язків між підприємствами, що перебувають на різних стадіях технологічного циклу визначеного товару (або групи товарів)» [14, с. 70]. Таке трактування потребує уточнення в напрямі визначення основної мети інтеграції.

Таким чином, для уточнення категоріально-понятійного апарату $\epsilon$ доцільним здійснити декомпозиційний аналіз поняття «вертикально інтегрована структура» на підставі формалізації характерних іiі ознак (табл. 3). Зауважимо, що в межах різних наукових підходів автори визначають характерні особливості вертикальної інтеграції по-різному. Наприклад, пріоритетною і визначальною ознакою вертикальної інтеграції М.Адельман вважає наявність контролю над стадіями виробничого процесу [2]. До цієї групи можна зарахувати і Л.П. Куца, який визначає поняття вертикальної інтеграції як розширення діяльності (i/або контролю) підприємства вздовж технологічно-збутового ланцюга для заміни ринкових трансакцій на інші можливі форми контрактів (наприклад, довгострокові контракти, внутрішні процеси). Автор у трактуванні вертикальної інтеграції як передумову збільшення контролю визначає розширення діяльності [9, с. 42].

Інші автори неодмінною умовою вертикально інтегрованих структур вважають зростання доданої вартості, тобто пріоритетним визначають фінансовий ефект від об’єднання. Недоліком такого підходу є неврахування організаційного ефекту від інтеграції (тобто, нівелювання чинників, пов'язаних із управлінням та відповідальністю за результати діяльності). На відміну від цього підходу, А.Серобян у трактуванні вертикальної інтеграції пріоритетною вважає ознаку відповідальності керуючої компанії за кінцевий варіант виробництва [13]. Автор також розглядає організаційні аспекти вертикальної інтеграції, визначаючи ії як процес розширення структури компанії, об'єднання кількох стадій виробництва у єдиний технологічний цикл тощо.

Таблиия 3

Результат декомпозиційного аналізу терміна «вертикально інтегрована структура» на складові елементи (складено авторами)

\begin{tabular}{|c|c|c|}
\hline $\begin{array}{l}\text { № } \\
3 / n\end{array}$ & Характерна ознака & Елементи визначення терміна «вертикально інтегрована структура» \\
\hline 1 & Іден & ПК \\
\hline 2 & Спосіб виникнення & шляхом об’єднання фінансових, виробничих, трудових ресурсів \\
\hline 3 & Суб’єкти інтеграції & різноманітні організаційно-правові форми \\
\hline 4 & $\begin{array}{l}\text { Зв’язки між } \\
\text { суб'єктами інтеграції }\end{array}$ & $\begin{array}{l}\text { пов’язані технологічним циклом (процесом постачання, виробництва та } \\
\text { реалізації продукції) }\end{array}$ \\
\hline 5 & Мета інтеграції & $\begin{array}{l}\text { одержання максимального синергетичного ефекту та стратегічних } \\
\text { конкурентних переваг }\end{array}$ \\
\hline \multicolumn{3}{|c|}{$\begin{array}{l}\text { Вертикально інтегрована структура - це форма функціонування підприємницької структури, яка } \\
\text { виникла шляхом об'єднання фінансових, виробничих, трудових ресурсів суб’єктів різноманітних } \\
\text { організаційно-правових форм, що пов'язані технологічним циклом (процесом постачання, } \\
\text { виробництва та реалізації продукції) } 3 \text { метою одержання максимального синергетичного ефекту та } \\
\text { стратегічних конкурентних переваг }\end{array}$} \\
\hline
\end{tabular}


Під час дослідження вертикальної інтеграції важливим питанням є визначення іiі напрямів, форм та ступенів. Етимологічне значення терміна «напрям» $є$ різностороннім, однак найбільш придатним для нашої предметної області $\epsilon$ таке: напрям - це шлях діяльності, розвитку кого-, чого-небудь; спрямованість якоїсь дії, явища [3]. Під напрямом вертикальної інтеграції будемо розуміти спрямованість вертикальної інтеграції. Виокремлення напрямів вертикальної інтеграції достатньо чітко обгрунтовано у статті А.Ігнатюк [6]: авторка розглядає інтеграцію «вперед» (пряму) та інтеграцію «назад» (зворотну), однак не уточнює особливостей кожного з цих напрямів. Соловей Ю., ідентифікуючи напрями вертикальної інтеграції, виокремлює «інтеграцію вниз» (коли у підприємства виникають інтеграційні зв'язки 3 підприємством-постачальником) та «інтеграцію вгору» (аналогічні зв'язки виникають 3 підприємством-споживачем) [14]. Автор справедливо зазначає, що вектор інтеграції ідентифікувати складно, особливо в аграрних підприємствах, оскільки вони забезпечують практично повний технологічний цикл.

Напрями економічної інтеграції у харчовій промисловості, що визначають О.Коваленко й О.Станіславик [7]: 1) державна підтримка попиту на продукцію; 2) розвиток наукових зв'язків; 3) розвиток торговельного співробітництва; 4) створення спільних підприємств; 5) кооперація інвестиційних проєктів; 6) співпраця у сфері використання ресурсів, міграції, узгодження політики у сфері підготовки кадрів тощо.

Під напрямами можливої вертикально здійсненої інтеграції будемо розуміти інтеграцію, спрямовану на: 1) розвиток виробничих зв'язків; 2) об'єднання фінансових ресурсів; 3) реалізацію інноваційноінвестиційних проєктів; 4) розвиток кадрового потенціалу. Напрями вертикальної інтеграції залежать від основної мети іiї здійснення та основних об’єктів, на розвиток яких спрямована вертикальна інтеграція. Під час вивчення цього питання, у праці [9] виокремлено два її ступені: 1) повна вертикальна інтеграція; 2) квазіінтеграція. Під квазіінтеграцією слід розуміти такий ступінь інтеграції, який характеризує відносини між вертикально пов'язаними підприємствами, які об'єднують риси довгострокових контрактів та повного володіння (наприклад, авансові платежі, вкладення в акціонерний капітал без контрольного пакета акцій тощо).

У межах повної вертикальної інтеграції автор вирізняє такі форми: 1) природна інтеграція; 2) злиття та поглинання. В межах квазіінтеграції: 1) стратегічні альянси; 2) спільні підприємства; 3) довгострокові контракти; 4) володіння активами на різних стадіях технологічного ланцюга; 5) перехресне володіння акціями; 6) франчайзинг. На погляд авторів, таку форму, як злиття та поглинання, слід доповнити приєднанням, що також відображає вертикальну інтеграцію шляхом укрупнення підприємств. У деяких наукових працях додатково представлено такий вид вертикальної інтеграції, як інтеграція власності, за якої підприємство, що є інтегратором, одержує у власність частину активів [15].

Актуальним питанням $є$ вплив факторів зовнішнього середовища на ступінь вертикальної інтеграції. Його досліджували у різних аспектах [4, 6, 9]. До основних факторів можна зарахувати: 1) стадію життєвого циклу продукту; 2) ефективність функціонування ринкового механізму; 3) тип конкуренції; 4) специфічність та складність продукції, що виробляється.

Характеристику форм вертикальної інтеграції у розрізі ступеня повної вертикальної інтеграції та квазіінтеграції наведено у таблиці 4.

Законодавчі акти, наприклад, Господарський кодекс України [5], виокремлює такі ознаки класифікації підприємств в цілому та вертикально інтегрованих структур зокрема:

1) за формою власності - приватне, колективне, державне (комунальне) підприємство;

2) за способом формування статутного капіталу (унітарні та корпоративні підприємства);

3) за кількістю працюючих (мікропідприємство, мале, середнє та велике підприємство);

4) за організаційно-правовими формами: асоціації, корпорації, консорціуми, концерни та інші види об'єднань. У свою чергу їх можна класифікувати за ознаками: договірні (корпорації, асоціаціі); статутні (концерни, консорціуми); інші об’єднання (фінансово-промислові групи, холдинги).

Оцінка закордонного досвіду функціонування вертикально інтегрованих структур дозволяє додатково виокремити ще такі їх види, як пул, картель, синдикат, трест. Види інтеграційних об'єднань, характерних для інших країн світу:

1) Канада, Китай, Німеччина, Франція, Англія - картелі, синдикати;

2) США - трести; холдинги, конгломерати;

3) Канада - асоціації, кооперативи;

4) Данія, Швеція, Фінляндія - кооперативи.

Доповнюючи класифікацію вертикально інтегрованих структур, представлену у Господарському Кодексі, О.Ніценко [11] додає такі ознаки, як: належність капіталу; технологічна, територіальна цілісність; географічне охоплення; статус самостійності; можливість впливу на інший суб'єкт господарювання. На погляд авторів статті, такі ознаки класифікації, як ступінь самостійності та можливість впливу на суб'єкт, дублюють одна одну, оскільки незалежність (самостійність) структури визначається і наявністю певного впливу. 
Характеристика форм вертикальної інтегращії у розрізі ступеня повної вертикальної інтеграції

та квазіінтеграчї (складено авторами за [5, 6, 9, 11])

\begin{tabular}{|c|c|c|c|c|c|}
\hline $\begin{array}{l}\text { № } \\
3 / n\end{array}$ & Форма & Характеристика форми & Переваги & Недоліки & Сфера застосування \\
\hline 1 & 2 & 3 & 4 & 5 & 6 \\
\hline \multicolumn{6}{|c|}{ Повна вертикальна інтеграція } \\
\hline 1 & $\begin{array}{l}\text { Природна } \\
\text { інтеграція }\end{array}$ & $\begin{array}{c}\text { Розвиток виробництва за рахунок } \\
\text { внутрішніх джерел; об’єднання різних } \\
\text { стадій технологічного процесу; } \\
\text { збереження сформованої організації } \\
\text { виробництва; збереження контролю } \\
\text { над власністю }\end{array}$ & $\begin{array}{c}\text { Тісний взаємозв’язок нової ланки } \\
\text { бізнесу з наявними сформованими } \\
\text { потужностями підприємства; } \\
\text { еволюційний розвиток процесу } \\
\text { інтеграції; удосконалення сфери } \\
\text { внутрішньовиробничих відносин }\end{array}$ & $\begin{array}{c}\text { Обмеження } \\
\text { можливостей суб’єктів } \\
\text { господарювання, які } \\
\text { функціонують на } \\
\text { ринках, що швидко } \\
\text { розвиваються }\end{array}$ & $\begin{array}{c}\text { Малі та середні } \\
\text { підприємства }\end{array}$ \\
\hline 2 & $\begin{array}{c}\text { Злиття i } \\
\text { поглинання }\end{array}$ & $\begin{array}{c}\text { Злиття - об’єднання підприємств } \\
\text { (шляхом створення нової юридичної } \\
\text { особи або приєднання підприємств до } \\
\text { головного підприємства) у результаті } \\
\text { якого власники (акціонери) } \\
\text { підприємств, що об’єднуються, } \\
\text { здійснюватимуть контроль над усіма } \\
\text { чистими активами об'єднаних } \\
\text { підприємств з метою досягнення } \\
\text { подальшого спільного розподілу } \\
\text { ризиків і вигід від об’єднання }\end{array}$ & $\begin{array}{c}\text { Можливість швидше адаптувати } \\
\text { новий бізнес (або нову стадію } \\
\text { технологічного циклу) до } \\
\text { існуючого технологічного ланцюга }\end{array}$ & $\begin{array}{c}\text { Складності } \\
\text { організаційного } \\
\text { характеру, що } \\
\text { обумовлені } \\
\text { об’єднанням ключових } \\
\text { технологій, } \\
\text { компетенцій, функцій }\end{array}$ & $\begin{array}{c}\text { Середні та малі } \\
\text { підприємства. Часто } \\
\text { підприємства, що } \\
\text { перебувають у } \\
\text { кризовому стані }\end{array}$ \\
\hline \multicolumn{6}{|c|}{ Квазіінтеграція } \\
\hline 1 & $\begin{array}{l}\text { Стратегічні } \\
\text { союзи } \\
\text { (альянси) }\end{array}$ & $\begin{array}{c}\text { Союз функціонує на підставі } \\
\text { об’єднання ресурсів, компетенцій, } \\
\text { інших стратегічних ресурсів з метою } \\
\text { зростання конкурентних переваг } \\
\text { новоствореного союзу; союз } \\
\text { оформлений на підставі договору про } \\
\text { співпрацю }\end{array}$ & $\begin{array}{l}\text { Зростання конкурентних переваг; } \\
\text { скорочення трансакційних витрат }\end{array}$ & $\begin{array}{c}\text { Самостійність } \\
\text { підприємств-членів } \\
\text { союзу, що ускладнює } \\
\text { координацію між ними }\end{array}$ & $\begin{array}{c}\text { Картелі, асоціації, } \\
\text { синдикати, трести, } \\
\text { консорціуми, холдинги, } \\
\text { ПФГ }\end{array}$ \\
\hline
\end{tabular}


Закінчення табл. 4

\begin{tabular}{|c|c|c|c|c|c|}
\hline 1 & 2 & 3 & 4 & 5 & 6 \\
\hline 2 & $\begin{array}{c}\text { Спільні } \\
\text { підприємства }\end{array}$ & $\begin{array}{c}\text { Вертикальний альянс, коли два } \\
\text { підприємства утворюють третє, що } \\
\text { задіяне у технологічному ланцюзі й } \\
\text { знаходиться під їх контролем }\end{array}$ & $\begin{array}{c}\text { Обмеження ризику інвестора } \\
\text { окремим проєктом }\end{array}$ & $\begin{array}{c}\text { Складність координації } \\
\text { між трьома } \\
\text { підприємствами }\end{array}$ & $\begin{array}{c}\text { Спільне володіння } \\
\text { сировинними } \\
\text { джерелами для } \\
\text { функціонуючих } \\
\text { підприємств-власників, } \\
\text { спільне використання } \\
\text { виробничих площ тощо }\end{array}$ \\
\hline 3 & $\begin{array}{l}\text { Довгострокові } \\
\text { контракти }\end{array}$ & $\begin{array}{c}\text { Інтеграція, що здійснюється на } \\
\text { підставі укладання довгострокового } \\
\text { контракту, що формує довготривалі } \\
\text { взаємовідносини між підприємствами }\end{array}$ & $\begin{array}{c}\text { Диверсифікація ризиків шляхом } \\
\text { передачі частини ризику на } \\
\text { кінцевого виробника готової } \\
\text { продукції; орієнтація на } \\
\text { перспективу }\end{array}$ & $\begin{array}{c}\text { Невизначеність } \\
\text { зовнішнього } \\
\text { середовища, що може } \\
\text { вплинути на } \\
\text { припинення } \\
\text { довгострокових } \\
\text { відносин } \\
\end{array}$ & $\begin{array}{c}\text { Договори з } \\
\text { виробниками- } \\
\text { постачальниками, } \\
\text { підприємствами- } \\
\text { дилерами тощо }\end{array}$ \\
\hline 4 & $\begin{array}{c}\text { Володіння } \\
\text { активами }\end{array}$ & $\begin{array}{c}\text { Здійснюється на різних стадіях } \\
\text { технологічного ланцюга; керівництво } \\
\text { активами здійснюють зовнішні } \\
\text { постачальники }\end{array}$ & Диверсифікація ризиків & $\begin{array}{c}\text { Контроль зовнішніх } \\
\text { постачальників за } \\
\text { ресурсами }\end{array}$ & Корпорації \\
\hline 5 & $\begin{array}{c}\text { Перехресне } \\
\text { володіння } \\
\text { акціями }\end{array}$ & $\begin{array}{c}\text { Ситуація, коли, наприклад, } \\
\text { материнська корпорація володіє } \\
\text { акціями однієї або більше корпорацій, } \\
\text { які водночас є акціонерами такого } \\
\text { материнського АТ }\end{array}$ & Диверсифікація ризиків & $\begin{array}{c}\text { Складність здійснення } \\
\text { фінансового контролю, } \\
\text { обумовлена складністю } \\
\text { зв'язків між } \\
\text { акціонерними } \\
\text { товариствами } \\
\end{array}$ & Корпорації \\
\hline 6 & Франчайзинг & $\begin{array}{c}\text { Контроль підприємства за реалізацією } \\
\text { через франшизну мережу }\end{array}$ & $\begin{array}{c}\text { Наявність капіталу, значна } \\
\text { швидкість зростання, зниження } \\
\text { ризику, проникнення на вторинний } \\
\text { та третинний ринки }\end{array}$ & $\begin{array}{c}\text { Франшиза не дає } \\
\text { франчайзі повного } \\
\text { контролю над своїм } \\
\text { бізнесом; сплата роялті }\end{array}$ & $\begin{array}{c}\text { Франчайзингові } \\
\text { компанії, що мають } \\
\text { потенціал зростання }\end{array}$ \\
\hline
\end{tabular}




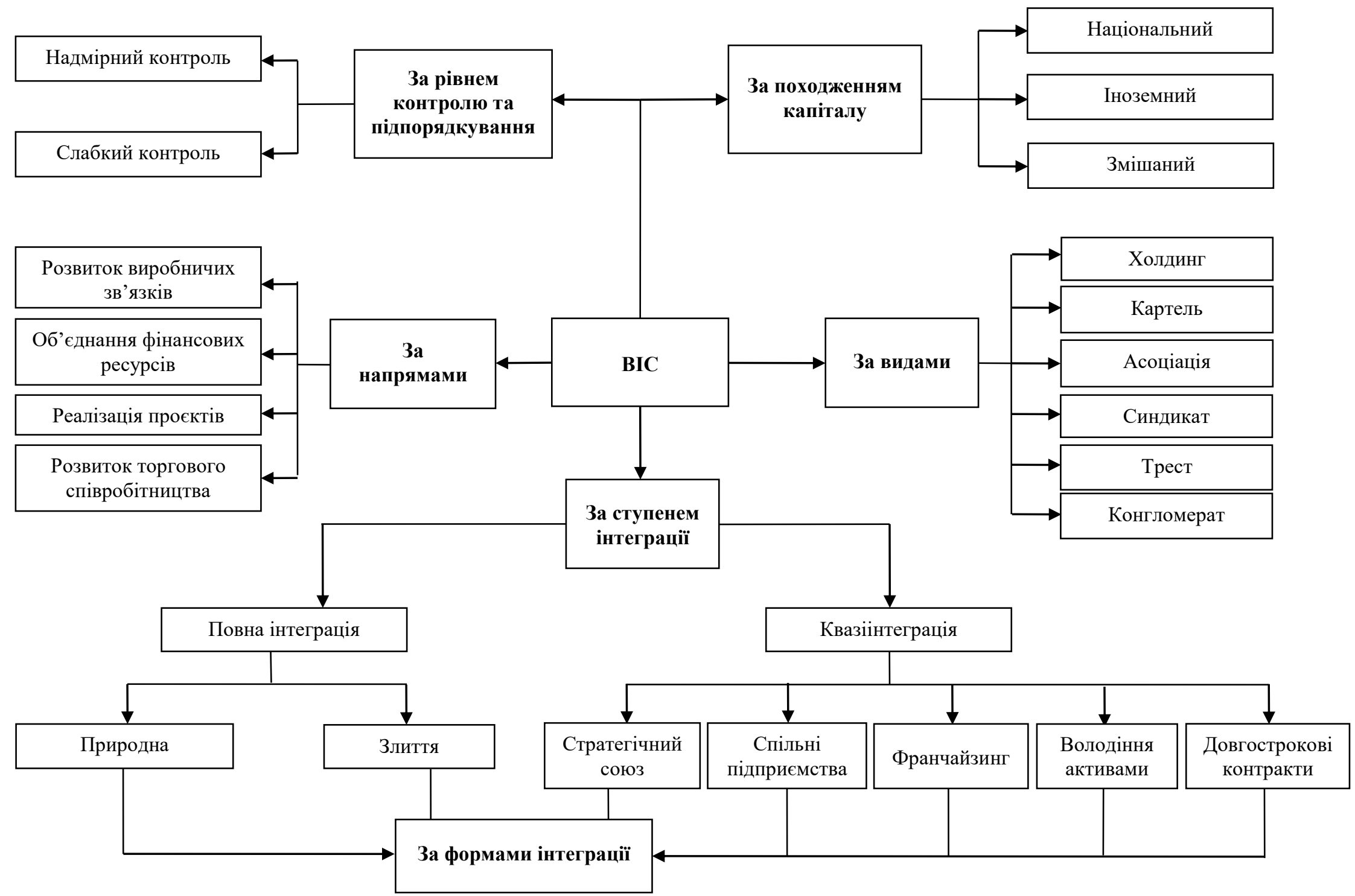

Рис. 2. Класифікаційна модель вертикально інтегрованих структур (складено авторами) 
Виокремлюючи в іншу групу вертикально інтегровані структури, закордонні вчені вирізняють такі іiі ознаки: класифікація за етапами розвитку структури (підприємницька, функціональна, поділена, матрична структури та динамічна мережа) та рівнем групування робочих завдань (або форми департаменталізації: функціональна, продуктова, географічна, процесна, клієнтська) [12].

Уточнену класифікаційну модель вертикально інтегрованих структур представлено на рисунку 2. У межах запропонованої класифікаційної моделі виокремлено такі ознаки класифікації та групи вертикально інтегрованих структур: 1) за походженням капіталу (національні, іноземні, змішані); 2) за видами (картель, холдинг, трест; асоціація; синдикат; конгломерат); 3) за ступенем інтеграції (повна інтеграція з поділом на природну та інтеграцію шляхом злиття; квазіінтеграція з поділом на стратегічні союзи (альянси), спільні підприємства, володіння активами, перехресне володіння акціями; франчайзинг; довгострокові контракти); 4) за напрямами інтеграції (розвиток виробничих зв'язків; акумуляція фінансових ресурсів; реалізація інноваційно-інвестиційних проєктів; розвиток торговельного співробітництва). На відміну від існуючих класифікацій, запропоновано нову ознаку: за рівнем контролю та підпорядкування, що дозволяє виокремити вертикально інтегровані структури з надмірним контролем та зі слабким контролем, що відображає ступінь залежності підпорядкованих суб'єктів від управлінських рішень головної (материнської) компанії. Запропонована класифікація сприятиме уточненню теоретичних основ, покладених в основу дослідження вертикально інтегрованих структур, та є базою для вивчення їх особливостей залежно від виокремлених ознак.

Сучасні тенденції та особливості створення й функціонування вертикально інтегрованих структур в Україні є такими: 1) переважає спосіб створення інтегрованих структур «зверху вниз»; 2) найбільш поширеними формами існування вертикально інтегрованих структур є холдинги, асоціації, фінансовопромислові групи; 3) холдинги, переважно, є базою для концентрації сировинних та переробних виробництв; 4) основною передумовою створення вертикально інтегрованих структур є забезпечення їх конкурентоспроможності на світовому ринку; 5) для вітчизняних вертикально інтегрованих структур $\epsilon$ характерною змішана структура власності; 6) вертикальна інтеграція найбільш поширена у нафтогазовій та хімічній галузях, машинобудуванні, аграрному секторі.

Висновки та перспективи подальших наукових досліджень. На підставі проведення декомпозиційного аналізу уточнено поняття «вертикально інтегрована структура», під яким слід розуміти форму функціонування підприємницької структури, що виникла шляхом об'єднання фінансових, виробничих, трудових ресурсів суб'єктів різноманітних організаційно-правових форм, які пов'язані технологічним циклом (процесом постачання, виробництва та реалізації продукції) 3 метою одержання максимального синергетичного ефекту та стратегічних конкурентних переваг. Уточнено класифікаційну модель вертикально інтегрованих структур, яка містить такі ознаки їх поділу: походження капіталу; види; ступінь інтеграції; напрям інтеграції. На відміну від існуючих класифікацій, запропоновано додати нову ознаку: за рівнем контролю та підпорядкування, що дозволяє виокремити вертикально інтегровані структури з надмірним контролем та структури зі слабким контролем, що відображає ступінь залежності підпорядкованих суб’єктів від управлінських рішень головної (материнської) компанії. Запропонована класифікація сприятиме уточненню теоретичних основ, покладених в основу дослідження вертикально інтегрованих структур, та $€$ базою для вивчення їх особливостей залежно від виокремлених ознак. Перспективи подальших наукових досліджень слід пов'язати 3 деталізацією окремих видів вертикально інтегрованих структур та розкриттям особливостей їх функціонування.

\section{Список використаної літератури:}

1. Авельцов Д. Тенденции развития корпоративного менеджмента / Д.Авельцов. - М. : ИНФРА-М, 1999. - 70 с.

2. Adelman M. Concept and statistical measurement of vertical integration / M.Adelman // Business Concentration and Price Policy. - Princeton : Princeton University Press, 1955.

3. Академічний тлумачний словник (1970-1980) [Електронний ресурс]. - Режим доступу : http://sum.in.ua/s/naprjam.

4. Бараненко С.П. Стратегическая устойчивость предприятия / С.П. Бараненко. - М. : Центр полиграф, 2004. $493 \mathrm{c.}$

5. Господарський кодекс України / Відомості ВРУ 2003, № 18, № 19-20, № 21-22, ст. 144 ; зі змінами від 16.10.2020.

6. Ігнатюк A. Вертикально-інтегровані структури на галузевих ринках України / А.Ігнатюк // Вісник Київського національного університету ім. Т.Шевченка. Серія : Економіка. - 2009. - № 5 (109). - С. 19-23.

7. Коваленко О.М. Умови та принципи формування вертикально-інтегрованих структур у харчовому комплексі / О.М. Коваленко, О.В. Станіславик // Економічний форум. - 2016. - № 1. - С. 230-240.

8. Криворучко О. Інформаційний простір підприємств вертикальної інтеграції / О.Криворучко // Вісник Київського національного торговельно-економічного університету. - 2016. - № 4. - С. 97-103 [Електронний pecypc]. - Режим доступу : http://nbuv.gov.ua/UJRN/Vknteu_2016_4_8.

9. Куи Л.П. Форми і ступені вертикальної інтеграції підприємств / Л.П. Куи // Інноваційна економіка. - 2012. № 5 (31). - C. 42-45. 
10. Маршак A. Слияния и поглощения для реструктуризации и повышения прибыльности бизнеса/ А.Маршак. - М. : ИК «Антон», 2000. - 32 с.

11. Ніценко B.C. Методологічні підходи до класифікації вертикально-інтегрованих структур в АПК/ B.С. Ніценко // Вісник ХНАУ. Серія : Економічні науки. - 2013. - № 7. - С. 171-180 [Електронний pecypc]. - Режим доступу : http://nbuv.gov.ua/UJRN/Vkhnau_ekon_2013_7_26.

12. Роббинз С.П. Менеджмент / С.П. Роббинз ; пер. с англ. - 8-е изд. - М. : ИД «Вильямс», 2007. - 1056 с.

13. Серобян А. Роль стратегічних ресурсів в управлінні вертикально-інтегрованими структурами / А.Серобян // Стратегія економічного розвитку України. - 2018. - № 43. - С. 35-42.

14. Соловей Ю. Особливості поширення інтегрованих структур в аграрному секторі економіки України/ Ю.Соловей // Аграрна економіка. - 2016. - Т. 9, № 3-4. - С. 68-73.

15. Соломчук Л.М. Вітчизняний та зарубіжний досвід створення інтегрованих структур / Л.М. Соломчук // Науковий вісник Херсонського державного університету. Серія : Економічні науки. - 2014. - Вип. 8, Ч. 4. C. $103-108$.

16. Стоянова-Коваль С. Особливості облікової політики у вертикально-інтегрованих компаніях / С.Стоянова-Коваль // Аграрний вісник Причорномор'я. - 2009. - № 49.

17. Уильямсон О.И. Вертикальная интеграция производства: соображения по поводу неудач рынка / О.И. Уильямсон ; пер. с англ. - СПб. : Экономическая школа, 1995. - С. 33-53.

\section{References:}

1. Avel'tsov, D. (1999), Tendentsii razvitiya korporativnogo menedzhmenta, INFRA-M, M., 70 p.

2. Adelman, M. (1955), «Concept and statistical measurement of vertical integration», Business Concentration and Price Policy, Princeton University Press, Princeton.

3. Akademichnyj tlumachnyj slovnyk (1970-1980), [Online], available at: http://sum.in.ua/s/naprjam

4. Baranenko, S.P. (2004), Strategicheskaya ustoichivost' predpriyatiya, Tsentr poligraf, M., 493 p.

5. VRU (2003), Gospodars'kyj kodeks Ukrai'ny, Vidomosti VRU, No. 18, No. 19-20, No. 21-22, st. 144, zi zminamy vid 16.10.2020.

6. Ignatjuk, A. (2009), «Vertykal'no-integrovani struktury na galuzevyh rynkah Ukrai'ny», Visnyk Kyi'vs'kogo nacional'nogo universytetu im. T.Shevchenka, Serija Ekonomika, No. 5 (109), pp. 19-23.

7. Kovalenko, O.M. and Stanislavyk, O.V. (2016), «Umovy ta pryncypy formuvannja vertykal'no-integrovanyh struktur u harchovomu kompleksi», Ekonomichnyj forum, No. 1, pp. 230-240.

8. Kryvoruchko, O. (2016), «Informacijnyj prostir pidpryjemstv vertykal'noi' integracii'», Visnyk Kyi'vs'kogo nacional'nogo torgovel'no-ekonomichnogo universytetu, No. 4, pp. 97-103, [Online], available at: http://nbuv.gov.ua/UJRN/Vknteu_2016_4_8

9. Kuc, L.P. (2012), «Formy i stupeni vertykal'noi' integracii' pidpryjemstv», Innovacijna ekonomika, No. 5 (31), pp. $42-45$.

10. Marshak, A. (2000), Sliyaniya i pogloshcheniya dlya restrukturizatsii i povysheniya pribyl'nosti biznesa, IK «Anton», M., 32 p.

11. Nicenko, V.S. (2013), «Metodologichni pidhody do klasyfikacii' vertykal'no-integrovanyh struktur v APK», Visnyk HNAU, Serija Ekonomichni nauky, No. 7, pp. 171-180, [Online], available at: http://nbuv.gov.ua/UJRN/Vkhnau_ekon_2013_7_26

12. Robbinz, S.P. (2007), Menedzhment, translation from English, 8th ed., ID «Vil'yams», M., 1056 p.

13. Serobjan, A. (2018), «Rol' strategichnyh resursiv v upravlinni vertykal'no-integrovanymy strukturamy», Strategija ekonomichnogo rozvytku Ukrai'ny, No. 43, pp. 35-42.

14. Solovej, Ju. (2016), "Osoblyvosti poshyrennja integrovanyh struktur v agrarnomu sektori ekonomiky Ukrai'ny», Agrarna ekonomika, Vol. 9, No. 3-4, pp. 68-73.

15. Solomchuk, L.M. (2014), «Vitchyznjanyj ta zarubizhnyj dosvid stvorennja integrovanyh struktur», Naukovyj visnyk Hersons'kogo derzhavnogo universytetu, Serija Ekonomichni nauky, Issue 8, Part 4, pp. 103-108.

16. Stojanova-Koval', S. (2009), «Osoblyvosti oblikovoi' polityky u vertykal'no-integrovanyh kompanijah», Agrarnyj visnyk Prychornomor'ja, No. 49.

17. Uil'yamson, O.I. (1995), Vertikal'naya integratsiya proizvodstva: soobrazheniya po povodu neudach rynka, translation from English, Ekonomicheskaya shkola, SPb., pp. 33-53.

Топило Вікторія Анатоліївна - аспірант кафедри фінансів і кредиту Державного університету «Житомирська політехніка».

Наукові інтереси:

- вертикальна інтеграція підприємств;

- бюджетування.

Данилко Валерій Кирилович - доктор економічних наук, професор, заслужений економіст України. Наукові інтереси:

- проблеми економіки і статистики природокористування та охорони довкілля;

- формування й використання екологічних фондів за умов сталого їх розвитку, всебічного удосконалення системи інформаційних ресурсів і статистичних спостережень у цій галузі господарської діяльності.

Стаття надійшла до редакції 22.01.2021. 